\title{
Design and development of a continuous culture system for studying rumen fermentation
}

\author{
HARRI MIETTINEN and JOUKO SETÄLÄ \\ Valio Finnish Co-operative Dairies' Association, \\ Research and Development Centre \\ P.O. Box 176, SF-00181 Helsinki, Finland
}

\begin{abstract}
The present report describes an in vitro continuous culture system to simulate rumen fermentation. The complete assembly consists of six culture vessels (liquid volume $700 \mathrm{ml}$ ) fed twice daily with finely ground feed. The artificial saliva enters the vessel continuously, and the effluent leaves it continuously through the overflow port. The intermittent stirring of the fermentor content and the $\mathrm{pH}$ regulation are automatically controlled by a desktop computer.

Two replicate experiments with ten fermentors given a diet of silage ( $50 \%)$ and barley $(50 \%)$ were made in order to evaluate the system. The results indicate that the system reaches steady-state conditions within three to five days, ammonia concentration being an exeption. It takes for the ammonia concentration approximately $11-14$ days to stabilize. The plateau values for the total volatile fatty acid (VFA) concentrations, the molar proportions of individual VFAs, and the ammonia concentrations were found to be within the accepted range in the rumen of animals given similar diets or in other artificial rumen systems. There was a tenfold decrease in the numbers of protozoa in the fermentors during the first four days of incubation. However, the average plateau value for the protozoa numbers $\left(2.5 \times 10^{4} / \mathrm{ml}\right)$ is in the same range as in the dual flow continuous culture systems. The efficiency of the microbial $\mathrm{N}$ production was higher than that usually observed in vivo or in vitro $(45 \mathrm{vs} .30 \mathrm{~g} / \mathrm{kg}$ organic matter digested).

The results indicate that this continuous culture system provides a reasonable estimate of rumen fermentation.
\end{abstract}

Index words: rumen fermentation, in vitro, continuous culture

\section{Introduction}

Various in vitro systems have been developed in order to overcome the difficulties encountered in in vivo studies of rumen fermen- tation. These systems can be roughly divided into simple batch cultures, designed for shortterm studies, and more complex continuous 


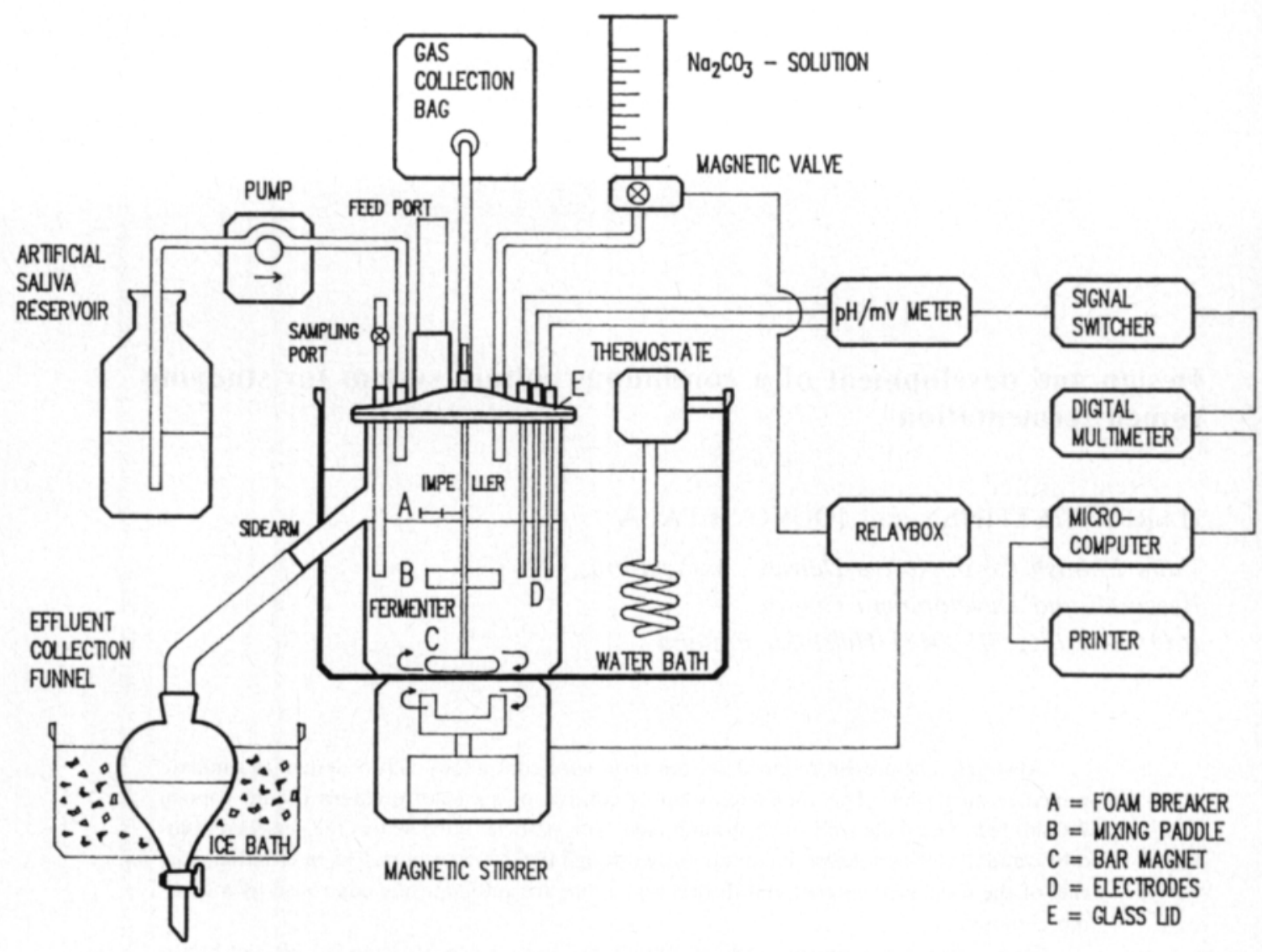

Fig. 1. Continuous culture apparatus.

culture systems, designed for long-term studies of rumen fermentation (for a review, see CZERKAWSKI 1986).

The continuous culture systems used in the studies of rumen metabolism can be classified into three categories. These are 1) the system developed by CZERKAWSKI and BRECKENRIDGE (1977), where the feed is retained in polyester bags within the vessel and changed periodically; 2) the system first described by HOOVER et al. (1976 a), in which solid feed is added to the fermentor and both solid and liquid outflow rates are controlled separately, and 3) the system first described by SLYTER et al. (1964) in which solid feed is added to the fermentors and the effluent is allowed to overflow to waste.

The apparatus described in the present paper is based on that of SLYTER et al. (1964).
The features of the system and some experiments are described. Some of this work has been published briefly elsewhere (MIETTINEN and SETÄLÄ 1988).

\section{Materials and methods}

\section{The continuous culture apparatus}

A schematic diagram of the continuous culture system is shown in Fig. 1. The complete assembly consists of six modified 1 litre glass fermentation vessels (Quicfit FV 1L) which are kept in an acrylic water bath at $39^{\circ} \mathrm{C}$. Magnetic stirrers are situated beneath each culture vessel. The stirrer drives an impeller with a bar magnet $(\mathrm{C})$, which has one mixing paddle (B) and a foam breaker (A). The glass lid (E) is connected gas-tightly on the vessel rims by 
means of vacuum grease and clamps. The lid has a large port ( $28 \mathrm{~mm}$ ID) for feed entry and smaller ports (17 mm ID) for artificial saliva infusion, sampling and $\mathrm{pH} /$ redox- electrodes (D). A silicone tube (length $300 \mathrm{~mm}, 28 \mathrm{~mm}$ ID) is permanently fixed on the feeding port.

Each vessel has a $23 \mathrm{~mm}$ ID sidearm situated so as to provide a fluid volume of $700 \mathrm{ml}$ in the fermentation vessel. The overflowing effluent passes into a modified 2 litre separatory funnel which, is kept in an ice bath, and into which $10 \mathrm{ml}$ of saturated $\mathrm{HgCl}_{2}$ is added to prevent further fermentation. The gas is collected into a 3 litre plastic gas collection bag. Artificial saliva is pumped into the fermentors continuously with a peristaltic pump (model IPS-8, Ismatec SA, Zurich). The pH in the fermentors is adjusted with saturated $\mathrm{Na}_{2} \mathrm{CO}_{3}$ solution added through magnetic valves.

The magnetic stirrers and the magnetic valves are coupled through a relay box to the desk-top computer (Hewelett-Packard HP-87, Corvallis). The $\mathrm{pH} /$ redox meters (Consort pvba, Belgium) are coupled through a signal switcher (Wavetec 604, San Diego) and a digital multimeter (Fluke 8840A, Eindhoven) to the HP-87.

\section{Operating conditions}

Artificial saliva (McDougall 1948), diluted 60:40 with water and containing $0.4 \mathrm{~g} / \mathrm{l}$ urea, was infused continuously to give an average outflow rate of $0.055 \mathrm{~h}^{-1}$. The feeds consisted of freeze-dried silage and dried barley $(50: 50 \%)$. The feeds were ground to pass a $1 \mathrm{~mm}$ screen and were fed at a rate of $24 \mathrm{~g} / \mathrm{d}$ $(21.5 \mathrm{gDM} / \mathrm{d}$ ), in two equal portions (at $8 \mathrm{am}$ and $3 \mathrm{pm}$ ).

The magnetic stirrers were operated intermittently, stirring the contents for $30 \mathrm{sec}$. every $4 \mathrm{~min}$. at approximately $110 \mathrm{rpm}$. The $\mathrm{pH}$ in the fermentors was controlled continuously and kept above 6.0 by adding saturated $\mathrm{Na}_{2} \mathrm{CO}_{3}$ solution through the magnetic valves when needed. The stirrers were turned on whenever $\mathrm{Na}_{2} \mathrm{CO}_{3}$ solution was added into the fermentors. The $\mathrm{pH}$ values in the fermentors were stored on minidisks and were also printed out on paper every hour. The desktop computer (HP-87) was programmed to take care of the operations listed above automatically. The redox potential was measured twice daily before the feed was added into the fermentors. The effluent which overflowed was collected every morning and stored at $-18^{\circ} \mathrm{C}$. Samples $(2 \mathrm{ml})$ for the analyses were taken from the fermentors before the feed was added and also from the effluent. The samples were frozen immediately at $-18^{\circ} \mathrm{C}$.

The fermentors were inoculated with rumen fluid from a rumen fistulated cow maintained on a silage and grain diet. The rumen fluid was removed from the animal approximately $2 \mathrm{~h}$ after feeding and strained through a layer of cheese cloth. The fermentors were charged with $600 \mathrm{ml}$ of this fluid.

\section{Analyses}

The dry matter content of the effluent was measured from approximately $25 \mathrm{~g}$ samples, which were taken during agitation from the daily effluent by a magnetic stirrer with a cut pipette. The samples were weighed and dried at $80^{\circ} \mathrm{C}$ for about $40 \mathrm{~h}$ and the dry matter (DM) content was determined. The dry matter digestibility was calculated for each sampling period as follows (Hoover et al. $1976 \mathrm{~b}$ ): $\%$ DM digestibility $=[$ feed DM $-($ effluent $\mathrm{DM}$ - buffer salt)]/feed $\mathrm{DM} \times 100$, where: feed $D M=g$ feed $/ 24 \mathrm{~h} \times \%$ feed $D M$ effluent $\mathrm{DM}=\mathrm{g}$ effluent $/ 24 \mathrm{~h} \times$ effluent $\mathrm{DM}$ buffer salt $=$ litres of artificial saliva $/ 24 \mathrm{~h} \times \mathrm{g}$ salt/litre + litres saturated $\mathrm{Na}_{2} \mathrm{CO}_{3} \times \mathrm{g}$ salt/ litre $+10 \mathrm{ml}$ saturated $\mathrm{HgCl}_{2} \times \mathrm{g}$ salt/litre

The amount of the organic matter fermented (OMF) was calculated from the amounts of the volatile fatty acids (VFA) produced using the formula proposed by DEMEYER and van NeVel (1975).

The VFAs were determined with a Perkin Elmer 8500 gas chromatograph with $10 \%$ SP-1200 and $1 \% \mathrm{H}_{3} \mathrm{PO}_{4}$ Chromosorb AW, 80-100 mesh column, using head-space tech- 
niques and an HS-101 autosampler. The samples were esterified by the method of OsL and GinZINGER (1986). L- and D-lactic acids and ammonia were determined as described by Rauramaa et al. (1987).

The microbial-N flow was measured from the freeze-dried sample (approx. $50 \mathrm{ml}$ ), taken during agitation from the daily effluent. Purine bases were used as a marker for microbial protein (ZINN and OWENS 1982). Microbial mass was separated from the daily effluent by the method of SMith and McAlLan (1974). It was freeze-dried and analyzed for Kjeldal $\mathrm{N}$ and purines. The protozoa numbers were determined in a $4 \times 4 \times 0.2 \mathrm{~mm}$ counting chamber following preparation, as described by Ogimoto \& Imai (1981).

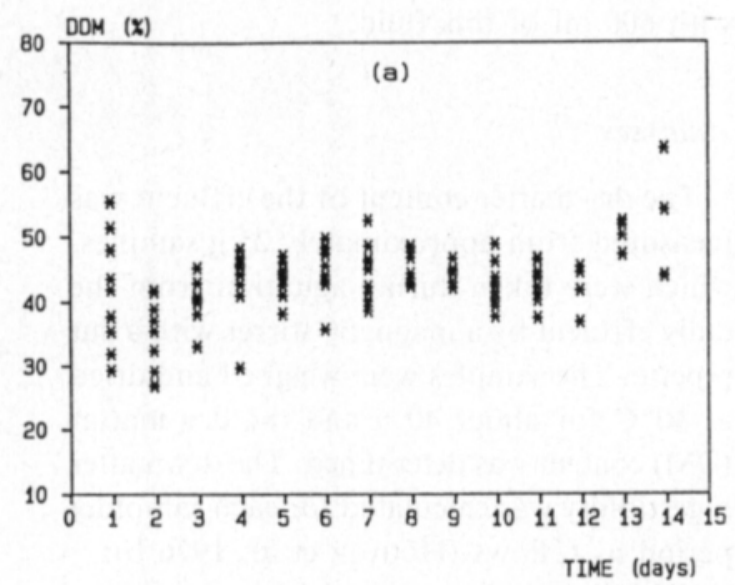

\section{Statistical treatment}

Two sets of trials with ten fermentors (four in experiment 1 and six in experiment 2 ) were made. Means, standard error of means (S.E.) and coefficients of variations $(\mathrm{CV} \%)$ were calculated according to standard statistical procedures. The F-test was used to measure the differences in coefficiencies of variations between the two experiments, using the equation: $\mathrm{C}_{1}{ }^{2} / \mathrm{C}_{2}{ }^{2}, \mathrm{df}_{1}=\mathrm{n}_{1}-1$ and $\mathrm{df}_{2}=\mathrm{n}_{2}-1$.

\section{Results}

Establishing a steady state

Of the two replicate experiments (each with a fresh inoculum) experiment 1 lasted for

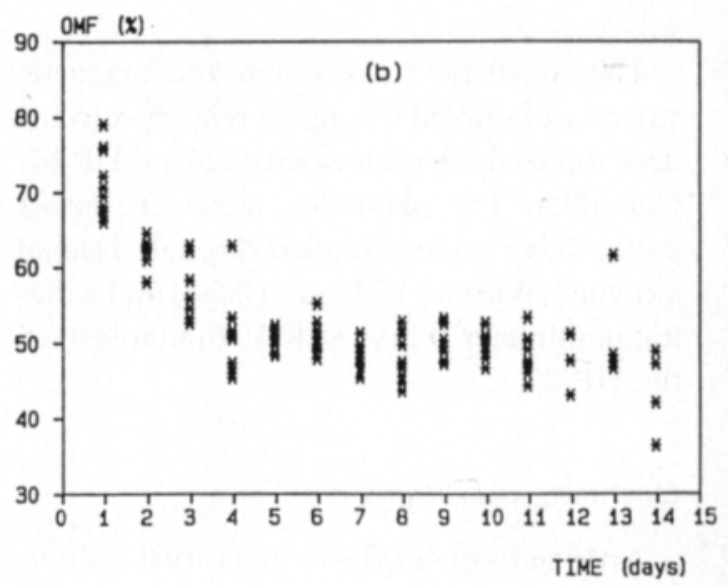

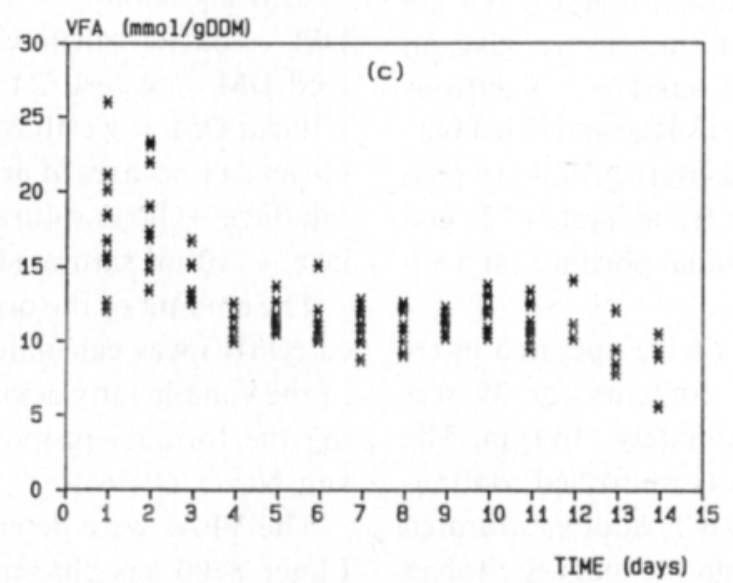

Fig. 2. Daily values for a) digested dry matter (DDM), b) organic matter fermented (OMF), calculated from volatile fatty acid (VFA) data and c) efficiency of VFA production. 
14 days and experiment 2 for 11 days. The daily values for each parameter are shown in Figs. 2-4.

The digestibility of dry matter (DDM) increased during the first four days of incubation and remained quite stable until the 13th day of incubation (Fig. 2a). The variation in DDM between the experiments and fermentors was considerable during the first and last days of incubation. The DM content of the effluent varied between 2.08 and $3.14 \%$, and was $2.44 \%$ on the average.

The changes in the proportion of organic matter fermented (OMF) in the fermentors and in the total VFA (TVFA) concentrations are quite similar because the amount of OMF was calculated from the VFAs produced. Both the amount of the OMF and the TVFA concentration decreased in the first three to four days of incubation and, after that reached a plateau (Figs. 2b, 3a). The changes seen in the efficiency of the VFA production $(\mathrm{mmol} / \mathrm{g}$ DM digested) were parallel to the changes seen in the TVFA concentration or in the amount of OMF (Fig. 2c).

There were no clear changes in the proportions of the individual VFAs during the incubations (Fig. 3b-d). However, there was a tendency for an increased proportion of acetic acid and a decreased proportion of butyric acid during the first three to four days of incubation. The proportion of butyric acid tended to increase towards the end of the incubation. The great variation in the propor-
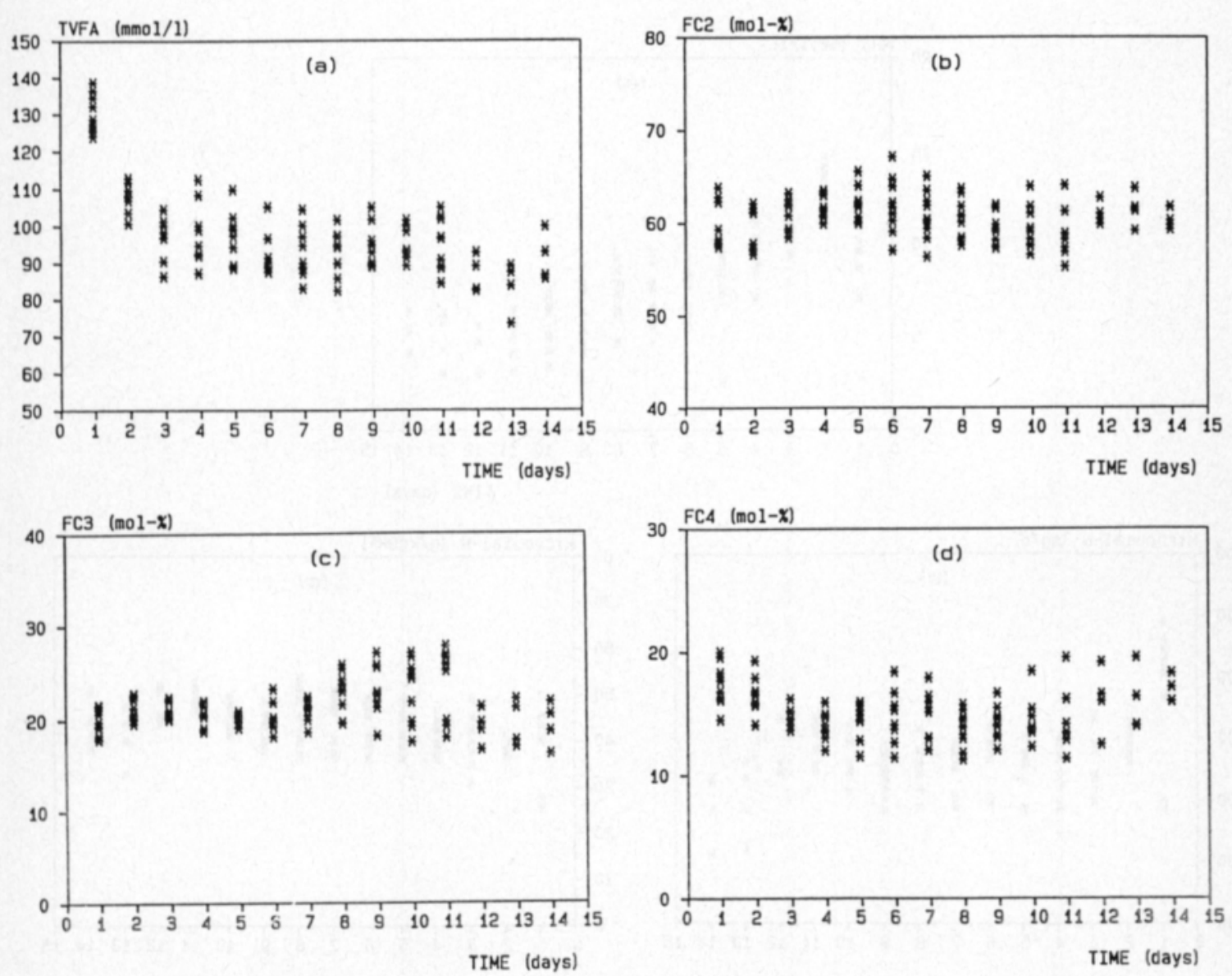

Fig. 3. Daily values for fermentor a) total volatile fatty acid concentration (TVFA), and proportions of b) acetate, c) propionate and d) butyrate. 
tion of propionic acid for eight to eleven days was due to the elevated levels determined in experiment 2 .

The concentration of lactic acid remained low $(<0.5 \mathrm{mM})$ throughout the experiment. However, some elevated concentrations up to $2.0 \mathrm{mM}$ were measured in the middle of the incubation period.

The concentration of ammonia decreased steadily until the 11th day of incubation (Fig. 4a). The microbial $\mathrm{N}$ flow decreased during the first three to four days, and remained quite stable until there was a drop after 12 days in experiment 1 (Fig. 4b). The efficiency of microbial $\mathrm{N}$ production ( $\mathrm{g} / \mathrm{kg} \mathrm{OMF}$ ) increased during the incubation (Fig. 4c).

The average content of total $\mathrm{N}$ and the purine bases of the bacterial mass isolated from the effluent were 93.6 and $62.6 \mathrm{mg} / \mathrm{g} \mathrm{DM}$, respectively. There was a slight increase in the purine base content of the bacterial mass during the experiments. The nucleic acid (RNA basis) $\mathrm{N}$ : total $\mathrm{N}$ ratio of the bacterial mass was, on the average, 0.124 . The content of purine bases measured from the effluent fluid was, on the average, $20.6 \mathrm{mg} / \mathrm{g} \mathrm{DM}$.

The protozoa numbers declined in the first four to five days of incubation, from $2.8 \times$ $10^{5} / \mathrm{ml}$ to $2.5 \times 10^{4} / \mathrm{ml}$, on average, and remained at this level for the remainder of the experiments.

\section{Characteristics of the system at steady state}

The values measured during days five to eleven were chosen to characterize the steady-
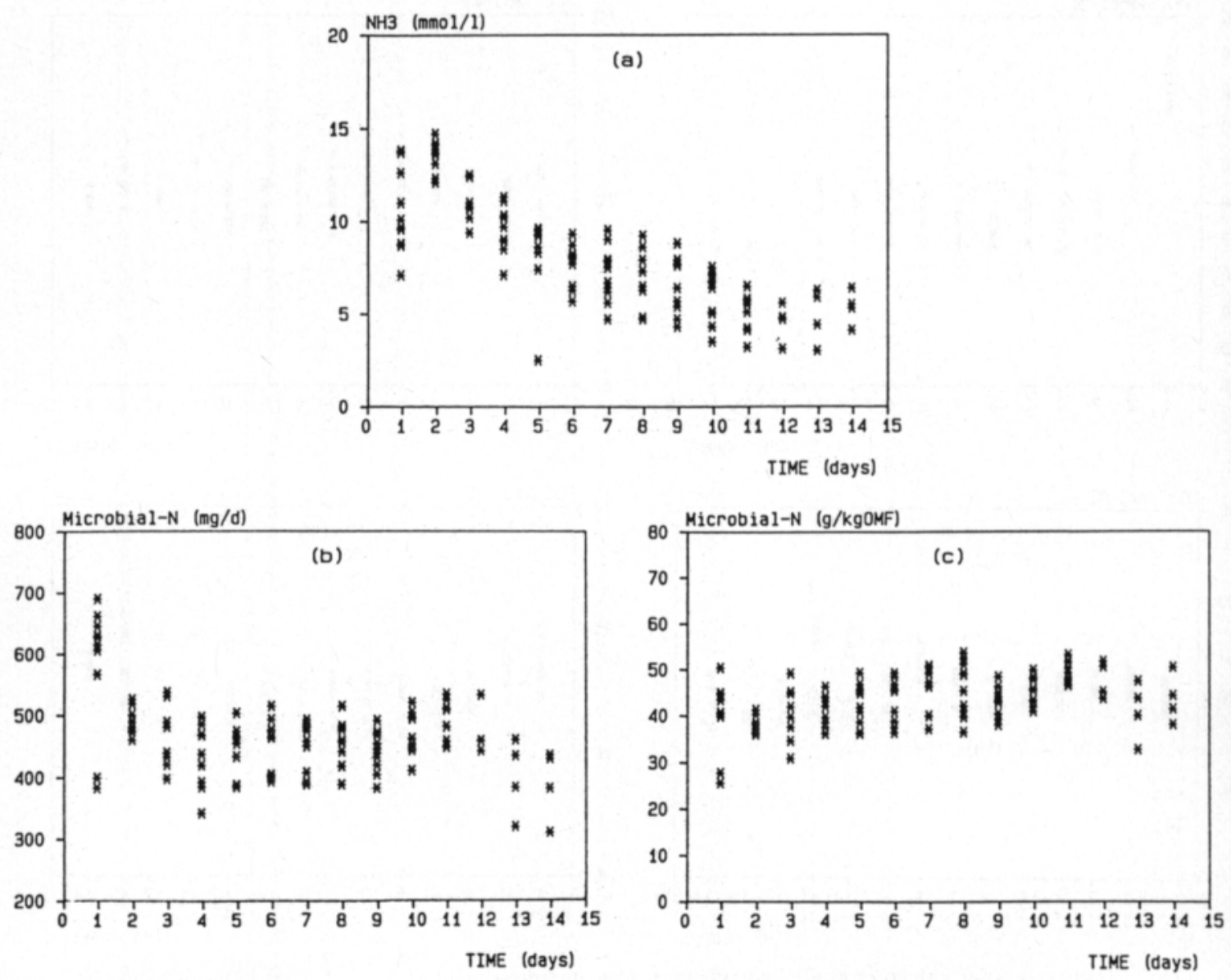

Fig. 4. Daily values for a) fermentor ammonia concentration, b) microbial-N flow, and c) production. 
Table 1. Typical properties of rumen contents in continuous cultures fed diets of silage and barley, and the average values in vivo fed diets of roughage and concentrates.

\begin{tabular}{|c|c|c|c|}
\hline & Mean' & S.E. & In vivo ${ }^{2}$ \\
\hline DM digestibility (\%) & 43.8 & 0.382 & 60 \\
\hline $\mathrm{OMF}^{3}(\%)$ & 49.4 & 0.289 & \\
\hline \multicolumn{4}{|l|}{ In fermentors } \\
\hline Total VFA (mM) & 94.0 & 0.721 & 100 \\
\hline \multicolumn{4}{|c|}{ Individual VFA (mol/100 mol total VFA) } \\
\hline Acetate & 60.3 & 0.308 & 65 \\
\hline Propionate & 21.9 & 0.322 & 20 \\
\hline Butyrate & 14.4 & 0.207 & 11 \\
\hline Valerate & 3.48 & 0.059 & 4 \\
\hline Lactic acid (mM) & 0.37 & 0.05 & \\
\hline Ammonia $(\mathrm{mM})^{4}$ & 5.1 & 0.23 & 7 \\
\hline \multicolumn{4}{|l|}{ From effluent } \\
\hline Total VFA (mmol/g DM digested) & 11.3 & 0.185 & 6 \\
\hline Microbial $\mathrm{N}$ flow (mg/d) & 455 & 4.67 & \\
\hline production ( $\mathrm{g} / \mathrm{kg}$ OMF) & 45.1 & 0.178 & 30 \\
\hline
\end{tabular}

I Mean values for two experiments (10 fermentors) during days five to eleven;

2 Adapted from literature (Czerkawskı 1986);

$3 \mathrm{OMF}=$ amount organic matter fermented, calculated from VFA data;

4 Values for days 11-14;

S.E. = standard error of mean.

state conditions in the fermentors. The mean values for different measurements together with typical in vivo data (CZERKAWSKı 1986) are shown in Table 1. The concentrations of isobutyrate and isovalerate are included in the concentrations of butyrate and valerate, respectively.

The dry matter digestibility was lower, the proportions of butyrate, the efficiency of VFA production (mmol/g DDM), and the efficiency of microbial $\mathrm{N}$ synthesis ( $\mathrm{g} / \mathrm{kg}$ OMF) were higher in the continuous culture compared with the average in vivo values.

Because the ammonia concentrations decreased until the 11th day of incubation, the values measured from days $11-14$ were used to characterize the steady-state value for the ammonia concentration in the fermentors.

After the first day of incubation, the redox potential in the fermentors was, on the average, $-170 \mathrm{mV}$ (SD 38.4).

\section{Variability of the measurements}

The variation of the different measurements made in the two experiments between the days of incubation and fermentors are expressed as coefficiencies of variation $(\mathrm{CV} \%)$ (Table 2). Daily values for each fermentor were used to calculate the $\mathrm{CV} \%$.

Table 2. Coefficients of variation $(\%)$ in experiments 1 $(d f=55)$ and $2(d f=61)$.

\begin{tabular}{lcc}
\hline Experiment & 1 & 2 \\
\hline DM digestibility (\%) & 15.2 & 9.91 \\
OMF (\%) & 15.0 & 13.8 \\
In fermentors & & \\
Total VFA (mM) & 12.1 & 12.5 \\
Individual VFA & & \\
(mol/100 mol total VFA) & & \\
$\quad$ Acetate & 2.77 & 3.06 \\
$\quad$ Propionate & 9.30 & 10.7 \\
$\quad$ Butyrate & 14.2 & 11.6 \\
$\quad$ Valerate & 15.6 & 14.5 \\
Lactic acid (mM) & $119.0^{\mathrm{a}}$ & $34.8^{\mathrm{b}}$ \\
Ammonia (mM) & $42.9^{\mathrm{a}}$ & $26.8^{\mathrm{b}}$ \\
From effluent & & \\
Total VFA (mmol/ & & \\
g DM digested) & $31.5^{\mathrm{a}}$ & $21.4^{\mathrm{b}}$ \\
Microbial N & 12.4 & 10.9 \\
flow (mg/d) & $12.9^{\mathrm{a}}$ & $8.48^{\mathrm{b}}$ \\
production (g/kg OMF) &
\end{tabular}

a,b Values in the same row with different superscripts differ $(\mathrm{p}<0.05) . \mathrm{OMF}=$ organic matter fermented. 
The variation was smallest for the proportion of acetate, and greatest for the lactic acid and ammonia concentrations. The great variation seen in the lactic acid concentrations was due to some individual high concentrations, especially in experiment 1 as discussed above. The great variation in the ammonia concentration was due to the steady decrease in the ammonia concentration during the experiments (Fig. 2h). The variation was considerable also for the efficiency of VFA production, which is a reflection of the variations in the amount of DM digested and in the total VFA concentration in the daily effluent. The $\mathrm{CV}$ for the effluent total VFA concentration was $15.6 \%$ in experiment 1 and $14.1 \%$ in experiment 2 . The variations in the total VFA and in the proportions of individual VFAs were slightly greater when measured from the effluent than from the fermentors.

The variation between the experiments in different parameters was significant for the DM digestibility, for lactic acid and ammonia concentrations, and for the efficiencies of the and microbial $\mathrm{N}$ production.

\section{Discussion}

The main criteria for successful artificial rumen systems include: 1) maintaining a balanced microbial population fairly representing that present in the rumen of animals fed similar diets; 2 ) provision for replication; and 3) ease of measurements. A system similar to that described here has been used earlier by Slyter et al. (1964), and Barry et al. (1977). However, several modifications of these systems were made in our system. These included the automatic control of $\mathrm{pH}$ and the intermittent mixing of the fermentor content.

Few comparisons between the bacterial populations existing in an artificial rumen and in vivo have been made. Slyter and Putnam (1967) identified bacterial species both from their continuous culture and from steers fed similar diets. They found no great difference between the bacterial populations in vitro and in vivo. However, the numbers of unidenti- fied butyrate-producing bacteria and the average proportion of butyrate were increased in the fermentors. A tendency to an increased production of butyrate during the fermentation was also found in this study.

The average total $\mathrm{N}$ content of the bacterial mass isolated from the effluent was higher than that observed by SMITH and McAllaN (1974) with cows. This may, however, be due to the smaller dietary contamination of the isolated bacterial mass in this experiment, as it has been proposed that the $\mathrm{N}$ content itself may be used as a tentative indicator of purity (the higher the $\mathrm{N}$ concentration, the purer the isolate) (Storm and Orskov 1983). The purine base content of the bacterial preparations and of the effluent were in the same range as those observed by UsHida et al. (1985) for bacterial preparations and duodenal digesta obtained from sheep. The nucleic acid N: total $\mathrm{N}$ ratio was lower than that observed by ZINN and OWEns (1986) with steers $(0.124$ vs. 0.149 ). This may be a consequence of the higher total $\mathrm{N}$ content of the bacterial mass.

The greatest difference between the ruminal microbial population in vivo and in the artificial rumen systems is the decrease in the protozoa numbers during the first three to four days of incubation, usually from $10^{5}$ to $10^{4}$ counts/ml (SLYTER et al. 1964, Hoover et al. 1976 a, Merry et al. 1987). This was also the situation in the present study and in the preliminary experiments with hay/barley or oven dried silage/barley diets, when the rumen fluid was taken from sheep (MIETTINEN and SETÄLÄ unpublished results). The large Holotrich species are the first to disappear from the fermentors. The principal types remaining are small Oligotrichs, mainly Entodinia spp.

The protozoa numbers decline mainly because their generation time is greater than their residence time in the fermentors, and they are washed out from the fermentors. In our experiments the dilution rate was 1.32 volumes/day, on the average, and the protozoa numbers at a steady-state were $2.5 \times$ $10^{4} / \mathrm{ml}$. Usually in the continuous culture 
systems based on a simple overflow (RUFNER et al. 1963, SLyter et al. 1964), or also in the dual flow systems, when the dilution rate is too high (HanNah et al. 1986) the protozoa survive only for short periods. The protozoa numbers in our system are at the same level as in dual flow systems (Hoover et al. 1976 a, Merry et al. 1987). The reasons for this may be the intermittent stirring of the fermentor content and the adjustment of the $\mathrm{pH}$ above 6.0. Both vigorous mechanical agitation and a low $\mathrm{pH}$ can adversely affect the protozoal capacity for survival.

The present results provided substantial confirmation of our preliminary finding that steady-state conditions in the system described can be achieved within three to four days (Miettinen and Setälä, unpublished results). The only exception in this respect is the ammonia concentration in the fermentors. The reasons for the slow decline in the ammonia concentration, which was also seen in the preliminary experiments, are difficult to explain. However, there may have been changes in the amount or type of bacteria in the fermentors which affected the hydrolysis and degradation of feed protein and/or the uptake of degradation products by the bacteria.

The plateau value for the ammonia concentration $(5 \mathrm{mM})$ is in the same range that in other artificial rumen systems (CRAWFORD et al. 1980 b, Merry et al. 1987) and near the optimal range $(3.5 \mathrm{mM})$ suggested by SATTER and SLYTER (1974) for optimal synthesis of microbial protein.

The plateau values for total VFA concentrations and molar proportions of the individual VFAs were fairly typical of diets con- taining $50 \%$ roughage (Table 1) (CZERKAwSKI 1986). The reason for the higher efficiency of the VFA production compared with typical values found in vivo (11 vs. $6 \mathrm{mmol} / \mathrm{g} \mathrm{DM}$ digested) (CZERKAwSKı 1986) or in the other studies with continuous cultures (CRAWFORD et al. 1980 a) may be the slightly lower DM digestion in our studies (43 vs. $50 \%$ ).

The daily microbial $\mathrm{N}$ flow from the fermentors was also in the same range as in the similar in vitro systems (CRAWFORD et al. 1980 a, Merry et al. 1987). The reason for the higher efficiency of the microbial $\mathrm{N}$ production than generally found in in vivo or in vitro systems (45 vs. $30 \mathrm{~g} / \mathrm{kg}$ OMD) (CZERKAWSKI 1986, KOMISARZUK et al. 1987) may be the lower amount of OMF. However, compared to the study of Komisarzuk et al. (1987), the amount of microbial protein synthetized was greater in our system in spite of the same amount of the OMF.

\section{Conclusions}

The results of this study indicate that the continuous culture system described can provide a reasonable estimate of rumen fermentation, and can thus be used as an alternative method for examining rumen fermentation without the cost and labor of studies made in vivo.

Acknowledgements. The authors are grateful to Mr. T. Moisio, Mr. E. Friman and Mr. H. Oranen for their skilled technical assistance, and to the staff of the Department of Animal Husbandry, University of Helsinki for providing the rumen fluid from the animals. The authors wish to express their sincere gratitude to Dr. A. B. McAllan for offering valuable advice and criticism.

\section{References}

Barry, T.N., Thompson, A. \& Armstrong, D.G. 1977. Rumen fermentation studies on two contrasting diets. 2. Comparison of the performance of an in vitro continuous-culture fermentation with in vivo fermentation. J. Agric. Sci., Camb. 89: 197-208.

Crawford, R.J. Jr., Hoover, W.H. \& Junkins, L.L.
1980 b. Effects of solids and liquid flows on fermentation in continuous cultures. II. Nitrogen partition and efficiency of microbial synthesis. J. Anim. Sci. 51: $986-995$.

-, Hoover, W.H. \& Knowlton, P.H. 1980 a. Effects of solids and liquid flows on fermentation in continuous 
cultures. I. Dry matter and fiber digestion, VFA production and protozoa numbers. J. Anim. Sci. 51: 975-985.

Czerkawskı, J.W. 1986. An introduction to rumen studies. 236 p. Pergamon Press: Oxford.

— \& Breckenridge, G. 1977. Design and development of a long-term rumen simulation technique (Rusitec). Br. J. Nutr. 38: 371-384.

DeMeyer, D.I. \& van Nevel, C.J. 1975. Methanogenesis, an integrated part of carbohydrate fermentation, and its control. In Digestion and Metabolism in the Ruminant. (ed. I.W. McDonald \& A.C.I. Warner) pp. 366-382. Armidale, New South Wales: The University of New England Publishing Unit.

Hannah, S.M., Stern, M.D. \& Ehle, F.R. 1986. Evaluation of a dual flow continuous culture system for estimating bacterial fermentation in vivo of mixed diets containing various soya bean products. Anim. Feed Sci. Tecnol. 16: 51-62.

Hoover, W.H., Crooker, B.A. \& Sniffen, C.J. 1976 a. Effects of differential solid-liquid removal rates on protozoa numbers in continuous cultures of rumen contents. J. Anim. Sci. 43: 528-534.

-, Knowlton, P.H., Stern, M.D. \& Sniffen, C.J. 1976 b. Effects of differential solid-liquid removal rates on fermentation parameters in continuous cultures of rumen content. J. Anim. Sci. 43: 535-542.

Komisarczuk, S., Merry, R.J. \& McAllan, A.B. 1987. Effect of different levels of phosphorus on rumen microbial fermentation and synthesis determined using a continuous culture technique. Br. J. Nutr. 57: 279-290.

McDougal.ı, E.O. 1948. Studies on ruminant saliva. I. The composition and output of sheep's saliva. Biochem. J. 43: 99-109.

Merry, R.J., Smith, R.H. \& McAll.an, A.B. 1987. Studies of rumen function in an in vitro continuous culture. Arch. Anim. Nutr., Berlin 37: 475-488.

Miettinen, H. \& Setalex, J. 1988. Use of a continuous culture system to study rumen metabolism. p. 400 in Proceedings VI World Conference on Animal Froduction, Helsinki. Gummerus Oy Jyvăskylă.

Ogıмото, K. \& IMAI, S. 1981. Atlas of rumen microbi- ology. p. 231. Japan Scientific Societies Press. Tokyo.

Ost, F. \& GinZINGER, W. 1986. Gaschromatographische bestimmung der freien fettsäuren in silage mit der head-space-technik. Landwirtsch. Forschung 39: 1-2.

Rauramaa, A., Setãlä, J., Moisio, T., Heikkilä, T. \& LAMPILA, M. 1987. The effect of inoculants and cellulase on the fermentation and microbiological composition of grass silage. I Biochemical changes in the silages. J. Agric. Sci. Finland 59: 361-370.

Rufner, W.H. Jr., Nelson, W.O. \& Wolin, M.J. 1963. Maintenance of the rumen microbial population in continuous culture. Appl. Microbiol. 11: 196-201.

SAtTer, L.D. \& Slyter, L.L. 1974. Effect of ammonia concentration on rumen microbial protein production in vitro. Br. J. Nutr. 32: 199-208.

Slyter, L.L., Nelson, W.O. \& Wolin, M.J. 1964. Modifications of a device for maintenance of the rumen microbial population in continuous culture. Appl. Microbiol. 12: 374-377.

- \& Putnam, P.A. 1967. In vivo vs. in vitro continuous culture of ruminal microbial populations. J. Anim. Sci. 26: 1421-1427.

Sмiтh, R.H. \& McAllan, A.B. 1974. Some factors influencing the chemical composition of mixed rumen bacteria. Br. J. Nutr. 31: 27-34.

Storm, E. \& Orskov, E.R. 1983. The nutritive value of rumen micro-organisms in ruminants. 1. Large-scale isolation and chemical composition of rumen microorganisms. Br. J. Nutr. 50: 463-470.

Ushida, K., Lassalas, B. \& Jouany, J-P. 1985. Determination of assay parameters for RNA analysis in bacterial and duodenal samples by spectrophotometry. Influence of sample treatment and preservation. Reprod. Nutr. Develop. 25(6): 1037-1046.

Zinn, R.A. \& Owens, F.N. 1982. Rapid procedure for quantifying nucleic acid content of digesta. In Protein Requirements for Cattle (ed. F.N. Owens) pp. 26-30. Oklahoma State University. MP-109.

- \& OWENS, F.N. 1986. A rapid procedure for purine measurement and its use for estimating net ruminal protein synthesis. Can. J. Anim. Sci. 66: 157-166.

Ms received October 21, 1988 


\section{Jatkuvatoimisen fermentorisysteemin (ns. keinopötsin) rakenne ja soveltuvuus pötsikäymisten tutkimiseen}

\author{
Harri Miettinen ja Jouko Setälä \\ Valion tutkimus- ja tuotekehityskeskus \\ PL. 17600181 Helsinki
}

Tutkimuksessa selvitettiin ns. keinopötsijărjestelmăn rakennetta ja soveltuvuutta märehtijöiden pötsikäymisten tutkimiseen. Järjestelmä käsittaaä kokonaisuudessaan 6 fermentoriastiaa (nestetilavuus $700 \mathrm{ml}$ ) jotka pidetäăn $39^{\circ} \mathrm{C}$ asteisessa vesihauteessa. Kokeen alussa fermentoriastioihin pannaan $\mathrm{n}$. $600 \mathrm{ml}$ juustokankaan läpi suodatettua pötsinestettä. Jatkuvan lăpivirtauksen aikaansaamiseksi fermentoreihin pumpataan jatkuvasti koostumukseltaan lehmän sylkeả vastaavaa puskuriliuosta halutulla nopeudella. Fermentoreista ylivuotoputkea pitkin vuotavan pötsinesteen ja hajoamattoman rehumassan seos kerảtäản ylivuotoastioihin jotka tyhjennetảän päivittäin. Fermentoreiden sisältỏả sekoitetaan jaksottaisesti sảădettaavän ohjelman mukaisesti. Fermentoreihin lisätään kahdesti pảivăssa nienoksi jauhettua kuivaa rehua. Fermentoreiden $\mathrm{pH}$ pidetāän halutulla tasolla emäsliuoksen avulla. Sekoituksen ja pH:n säătely tapahtuu automaattisesti pienoistietokoneen avulla.

Järjestelmän soveltuuvuuden tutkimiseksi suoritettiin kaksi koesarjaa yhteensä 10 fermentorilla. Fermentoreihin lisătty rehuannos $(24 \mathrm{~g} / \mathrm{pv}$.) koostui ohrasta $(50 \%)$ ja pakastekuivatusta säilörehusta $(50 \%)$. Fermentoreista ja ylivuodosta otetuista năytteistä maaăritettiin rehuannoksen kuiva-aineen ja orgaanisen aineen sulavuudet, haihtuvat rasvahapot, maitohappo, ammoniakki, mikrobityppi ja alkueläinten lukumäärät.

Rehun sulavuuden, haihtuvien rasvahappojen ja mikrobitypen suhteen tasapainotila fermentoreissa saavutettiin 3-5 päivässă. Ammoniakkipitoisuuden suhteen tasapainotilan saavuttaminen kesti n. 11-14 vrk. Alkuelăinten lukumaaără văheni ensimmăisten koepaaivien aikana n. kymmenesosaan alkuperäisestä.

Tasapainotilassa haihtuvien rasvahappojen pitoisuus ja yksittäisten rasvahappojen suhteet sekă ammoniakin pitoisuus vastasivat hyvin elăinkokeissa tai muissa keinopötsikokeissa vastaavanlaisella ruokinnalla saatuja tuloksia. Mikrobitypen synteesin tehokkuus oli tăssă systeemissä hieman suurempi tyypillisiin in vivo tai in vitro tuloksiin verrattuna. Alkueläinten lukumaaărăn văheneminen on tyypillistă kaikille keinopötsisysteemeille. Alkueläinten lukumaaără tasapainotilassa oli tăssä systeemissä samaa suuruusluokkaa kuin muissa vastaavanlaisissa keinopötseissä.

Kokeissa saadut tulokset osoittivat, että tässả kuvattua keinopötsijärjestelmäă voidaan käyttaaă märehtijöiden pötsikäymistapahtumien tutkimiseen. Järjestelmä tarjoaa siten vaihtoehdon kalliille ja työläille eläinkokeille. 